\title{
Changes in Cortisol Levels before and after Supportive Psychotherapy in Patients with Comorbid Cervical Cancer Distress with Depression Type
}

\author{
Perubahan Kadar Kortisol sebelum dan sesudah Psikoterapi Suportif pada Pasien \\ Kanker Serviks dengan Komorbiditas Distres Tipe Depresi
}

\author{
Laila Nuranna1, Kartiwa H Nuryanto', Andriansyah'1, Sylvia D Elvira, Bambang Sutrisna² \\ ${ }^{1}$ Department of Obstetrics and Gynecology \\ ${ }^{2}$ Department of Pathology Anatomy \\ Faculty of Medicine Universitas Indonesia/ \\ Dr. Cipto Mangunkusumo Hospital
}

Jakarta

\begin{abstract}
Objective: To prove the success of supportive psychotherapy that was provided as a distress therapy on advanced cervical cancer. Knowing the prevalence of distress type of depression in patient with epithelial cervical cancer, proving the benefits of psychotherapy supportive for distress can decreasing cortisol level in cervical cancer patient, can assess distress thermometer score, HAM-D17 score and scoring incident predictors of distress with depression type.
\end{abstract}

Methods: There were 32 subjects from 71 advanced cervical cancer patients had mild-moderate depression. Then randomization blocking was performed to determine a subject who entered the treatment group $(\mathrm{n}=16)$ who got supportive psychotherapy or control group who got common psychotherapy $(n=16)$. All of participants assessed the distress level with cortisol value, distress thermometer score, and HAM-D17 score before and after they got supportive psychotherapy.

Results: After the intervention of psychotherapy in the treatment group decreased HAM-D17 score, the average decline 7.53 (SB 3.34). The mean decreasing in the control group was 3.98 (SB 2.85). There is a significant difference in mean reduction in HAM-D17 scores on treatment and control groups with $p=0.003(p<0.005)$. There was decreasing blood cortisol level in the treatment group amounted to 39.43 , while the control group there was a drop of 1.59. The reduction of cortisol level in the treatment group and the control has a pvalue 0.302 . After got supportive psychotherapy, found a decreasing the average value of the thermometer distress in the treatment group 3.02 and the control group 2.51, with a p value more than 0.492 .

Conclusion: There were $45 \%$ of cervical cancer patients in the clinic experiencing distress disorder with depressive type. The blood cortisol level could be decreased by giving supportive psychotherapy with a mean decrease of $39.43 \mathrm{nmol} / \mathrm{l}$. There was a significant reduction in the level of depression (HAM-D17 score) of 7.53 points and distress thermometer impairment by 3 points after given supportive psychotherapy. Obtained scoring predictors for the occurrence of distress type of depression in patients with advanced cervical cancer with a sensitivity of $46.15 \%$ and a specificity of $89.47 \%$.

[Indones J Obstet Gynecol 2018; 6-3: 179-187]

Keywords: cervical cancer, cortisol, distress, distress thermometer, HAM-D17 score

\section{Abstrak}

Tujuan: Untuk membuktikan keberhasilan psikoterapi suportif yang diberikan sebagai terapi distress pada kanker serviks stadium lanjut. Mengetahui prevalensi distress tipe depresi pada pasien kanker serviks epitelial, manfaat psikoterapi suportif terhadap distress pasien kanker serviks stadium lanjut dalam menurunkan kadar kortisol, nilai thermometer distress, nilai HAM-D17 dan scoring predictor terjadinya distress tipe depresi pada pasien kanker serviks stadium lanjut.

Metode: Didapatkan 32 subjek penelitian dari 71 pasien kanker serviks stadium lanjut yang memenuhi kriteria inklusi (45\%) yang mengalami distress sedang-berat tipe depresi ringan-sedang dan selanjutnya dilakukan randomisasi blok untuk menentukan subjek yang masuk kelompok perlakuan $(n=16)$ dan kontrol $(n=16)$. Sampel penelitian akan diberi penerangan terlebih dahulu dan bila sudah dapat dimengerti dan dipahami maka pasien diminta untuk menandatangani lembar persetujuan. Setelah pasien menyetujui untuk ikut serta dalam penelitian, selanjutnya pasien akan dinilai tingkat distress dengan kadar kortisol, nilai thermometer distress, dan nilai HAM-D17 sebelum dan sesudah psikoterapi suportif.

Hasil: Setelah dilakukan intervensi psikoterapi pada kelompok perlakuan terjadi penurunan skor HAM-D17, rerata penurunannya 7,53 (SB 3,34). Rerata penurunan pada kelompok kontrol 3,98 (SB 2,85). Terdapat perbedaan yang bermakna penurunan rerata skor HAMD17 kelompok perlakuan dan kontrol dengan nilai $p=0,003(p<0,005)$. Terdapat penurunan kadar kortisol darah pada kelompok perlakuan sebesar 39,43 sedangkan pada kelompok kontrol terdapat penurunan sebesar 1,59. Penurunan kadar kortisol pada kelompok perlakuan dan kontrol ini memiliki nilai p 0,302. Setelah diberikan psikoterapi suportif, didapatkan penurunan rerata nilai thermometer distress pada kelompok perlakuan sebesar 3,02 dan pada kelompok kontrol sebesar 2,51 dengan nilai p lebih dari 0,492.

Kesimpulan: Terdapat 45\% pasien kanker serviks di poliklinik yang mengalami gangguan distress tipe depresi yang bermakna, penurunan kadar kortisol darah sesudah diberikan psikoterapi suportif dengan rerata penurunan sebesar 39,43 nmol/1 pada penderita kanker serviks yang mengalami distress tipe depresi, penurunan bermakna tingkat depresi (skor HAM-D17) sebesar 7,53 poin sesudah diberikan psikoterapi suportif pada penderita kanker serviks yang mengalami distress tipe depresi, penurunan nilai thermometer distress sebesar 3 poin sesudah diberikan psikoterapi suportif pada penderita kanker serviks yang mengalami distress tipe depresi dan didapatkan skoring prediktor terjadinya distress tipe depresi pada pasien kanker serviks stadium lanjut dengan sensitivitas $46,15 \%$ dan spesifisitas $89,47 \%$.

[Maj Obstet Ginekol Indones 2018; 6-3: 179-187]

Kata kunci: distress, kanker serviks, kortisol, skor HAM-D17, thermometer distress 


\section{INTRODUCTION}

The majority of cancer patients experience distress condition caused by the cancer itself and treatment they are going through. Research shows $20-40 \%$ of cancer patients experience meaningful distress. ${ }^{1}$ The prevalence of distress in gynecological cancer patients is around $30 \%$. Research on patients being treated at the hospital showed a high incidence of either depression (20-45\%) or delirium (increased from $15 \%$ to $75 \%$ due to the increasing severity of the disease). ${ }^{1}$

The most gynecological cancer in Indonesia is cervical cancer. Problems faced by patients ranging from cervical cancer-related disease such as vaginal bleeding, pelvic pain, smelly vaginal-discharge until sexual relationship problems which probably felt until died. All of these problems will lead to a meaningful distress of her life. Definition of distress in cancer patients is an uncomfortable multifactorial emotional experience that either comes from psychological problems or social/spiritual/religious problems that could interfere with their ability to face cancer, physical symptoms and the cancer therapy itself effectively (NCCN). ${ }^{1,2}$ The use of the word distress selected by the NCCN aims to eliminate or reduce the stigma attached to such words like psychiatric, psychological, or emotional. ${ }^{1,2}$ Screening and identification of psychological distress in the early presence of distress would make the management become more effective and therefore could improve the quality of cancer care management and improve the survival. ${ }^{1,2}$ NCCN (The National Comprehensive Cancer Network) recommends distress screening to all cancer patients, psychosocial therapy integration and the development of a treatment plan with referral to the psychosocial management center if needed into a routine cancer therapy in all cancer patients. ${ }^{1}$

NCCN recommends the use of distress thermometer to identify the presence of distress. Distress thermometer is a tool similar to the initial screening scale of measurement for pain: a value of 0 (no distress) up to a value of 10 (the most severe distress). In this study, the results of measurements of the distress thermometer are grouped into three groups namely the values 1-3 as a group of mild distress, 4-6 as a moderate distress group and 7-10 as a severe distress group. The current use of the distress thermometer has been used widely in integration of psychiatric counseling and psychosocial therapies into a better comprehensive service or hospitality for cancer patients. ${ }^{1,3}$

In addition to assessing distress condition, there is laboratory examination of cortisol, which is often known as the stress hormone which is the organism's response to stress and anxiety/restlessness. ${ }^{4}$ Cortisol is a hormone that is released through the glucocorticoid mechanism along the Hypothalamus-Pituitary-Adrenal (HPA) axis as a response to inflammation (Rhen and Cidlowski, 2005), stress and other stimulus (Chrousos and Gold, 2005) which roled as a regulator in important metabolic functions. ${ }^{5}$ Dallman, Tsigos, Chrousus, et al conclude cortisol level influenced by circadian cycles (diurnal rhythm) with the highest level in the morning and continues to diminish throughout the afternoon and evening and reached a nadir when the middle of the night. ${ }^{4,5}$ As a response of the body to face with the stress then the suprachiasmatic neurons in the hypothalamus secretes Corticotrophin-Releasing Hormone (CRH), which will further stimulate the secretion of AdrenoCorticotropic Hormone (ACTH) released from the pituitary which will eventually stimulate the adrenal cortex to release cortisol. Then negative feedback mechanism would happen by which cortisol would suppress the production of CRH and ACTH in hypothalamus and hypophysis. But in certain circumstances such as chronic inflammatory and cancer, found negative feedback is not well response so that diurnal cortisol rhythm disorder would happen. ${ }^{6}$

Zhang et al. declared glucocorticoid would stimulate gene expression of anti-apoptosis and act as antagonistic toward cytotoxic capability against epithelial cancer cells (solid tumors). ${ }^{7}$ Volde and Conzen found cortisol/glucocorticoids would inhibit the process of apoptosis in breast, cervical and ovarian cancer cells. ${ }^{6}$ In vitro model of ovarian cancer, cortisol can cause effects obtained by catecholamine; ability of tumor invasion (Nakane et al, 1990; Sood et al 2006), improved regulatory factors such as VEGF angiogenic-pro (Lutgendorf et al., 2003) and the expression of matrix metalloproteinase (Lutgendorf et al, 2008). ${ }^{8,9}$ Abercrombie et al. discovered that breast cancer patients with more advanced stages would have higher average cortisol level than patients with earlier stage and Sephton et al. also discovered the existence of the curve cortisol more ramps. ${ }^{8}$ 
A research in the relationship of diurnal cortisol level and survival in epithelial ovarian cancer patients revealed that an increasing one standard deviation of the cortisol level is associated with an increased risk of death of $46 \%$ and at group that have higher level of cortisol have a survival average 3.3 years whereas in the group who have lower cortisol level have a survival average of 7.3 years. And that's the important rationale of why the psychotherapy becomes an important basis because it attempts to decrease the cortisol level.

Stommel et al. reported cancer patients with a history of depression would have the risk of death 2, six times in the first 19 months after initial diagnosis of depression found. Faller et al. conducted a study on 103 cancer patients, demonstrated the state of depression that also related to decreased survival time. With regard to the potential direct impact on survival, the depression that arises would make a decrease in compliance against therapy, extended hospital care time, reduced the quality of life and ability to take care of themselves. ${ }^{10}$

While the definition of depression itself is a mood disorder characterized by the presence of abnormality in the mood, impaired psychomotor, impaired cognitive function and biorhythms disorders. Then to make diagnosis of depression using the diagnostic criteria for major depressive disorder based on DSM-V (Diagnostic and Statistical Manual of Mental Disorders Fifth edition) as a censorship. ${ }^{10}$ RSCM used screening diagnosis of depression according to SCID (Structured Clinical Interview for DSM)-I Indonesian version January 2000 v1.01. And proceed using the Hamilton Psychiatric Rating Scale for Depression (HAM-D17) as a tool to ensure the diagnosis of depression, assessing the success of therapy and categorizing depression scale based on score/total value calculated. HAM-D17 scale is a scale often used in clinical research as a golden standard.

Other scales than HAM-D17 are MontgomeryAsberg Depression Rating Scale (MADRS), the Beck Depression Inventory (BDI), the Zunf Self-Depression Rating Scale, the Wechsler Depression Rating Scale, the Raskin Depression Rating Scale, and others.

\section{METHOD}

This study was a clinical trials/randomized experimentsubtle parallel design. The intervention group was invasive cervical cancer epithelial type advanced stage (IIB - IVB) who have experienced distress level of moderate to severe depression-type with mild-moderate who get special Psychotherapy/supportive Psychotherapy (Department of Psychiatry). The comparison group is invasive cervical cancer epithelial type advanced stage (IIB IVB) who have experienced distress level of moderate to severe depression-type with mildmoderate who get Psychotherapy (Gynecologic Oncology Division). Determination of the distress level based distress thermometer which is determined by patients themselves with the explanation by Obstetrics and Gynecology doctor. In this study the results of measurements of the distress thermometer are grouped into three groups namely the values $1-3$ as a group of mild distress, the values 4-6 as distress groups and the values 7-10 as heavy distress group. In addition to the distress thermometer also added a questionnaire in the form of a list of 35 problems to help patients identify their problem quickly into five different categories: practical daily life issues, family problems, emotional problems, spiritual/religious problems and physical problems. The assessment and determination of the type of depression and distress degree of depression were done by a psychiatry doctor. The diagnosis of depression screening used by RSCM is SCID (Structured Clinical Interview for DSM)-I version the language Indonesia January $2000 \mathrm{v} 1.01$. Then proceed with using the Hamilton Psychiatric Rating Scale for Depression (HAM-D17) as a tool to ensure the diagnosis of depression, assessing the success of therapy and categorize the light weight depression based on score/total value that calculated. Category of the depression degree based on HAM-D17 is normal when the value $0-7$; mild depression when the value 8-13; depression are when the value of 14-18; severe depression when the value of 19-22. Inspection and measurement of patient's blood cortisol level conducted by the Biochemistry Laboratory Medical Faculty, University of Indonesia in Jakarta. Then the General Psychotherapy conducted in Gynecologic Oncology Division Clinic and Special Psychotherapy conducted in the Adult Psychiatry Polyclinic Department of RSUPN Dr. Cipto Mangunkusumo. Determination of the sample is randomized in sealed envelope. 
The inclusion criterion is cervical epithelial cancer patients with advanced stage (Stage IIB IVB) who are willing to participate in as a subject of research. Whereas the exclusion criterions are neuroendocrine type of cervical cancer, cervical cancer in pregnancy and cervical cancer patients who experience severe depression type of distress.

Some of the variables examined in this research include independent variables such as; age, education, marital status, advanced stage of cervical cancer, religion, occupation, parity and ethnicity and dependent variables such as; cortisol level, distress thermometer score, and HAM-D17 score. The involvement of these variables can be seen from research concept framework chart below:

\section{RESULTS AND DISCUSSION}

Purposive sampling method had been conducted from $14^{\text {th }}$ of June until $27^{\text {th }}$ of October 2016 at RSCM Gynecologic Oncology Clinic. Obtained the number of cervical cancer patients based on staging; stage IB 8 pts, stage IIA4 pts, stage IIB20 pts,stage IIIA 3 pts, stage IIIB34 pts, stage IVA1 pts and stage IVB1 pts. The number of the subject of advanced cervical cancer stage that successfully screened are 37 people, five subjects do not include the inclusion criteria; 4 subjects of mild distress and one subject suffered neuroendocrine type of cervical cancer. Then 32 subjects fulfilled the inclusion criteria; patients with cervical cancer stage IIB to IVB with moderate to severe distress and fulfilled mild to moderate distress criteria. To determine the subject, it needs to conduct block randomization; the subject of the treatment group $(n=16)$ and controls $(n=16)$. During the research in five weeks, there were drop out in both groups. There were 5 patients from the control group 1 patient passed away, 1 patient back to Java, 1 patient back to Ternate and 2 patients could not be reached), meanwhile 4 patients from experiment/treatment group (1 patient passed away, 1 patient back to Batam, 1 patient did not want to continue the research, and 1 patient could not be reach). Imputation of data needed to be done to create better and valid statistic analysis and results in both groups. The flowchart below describes the research subjects :

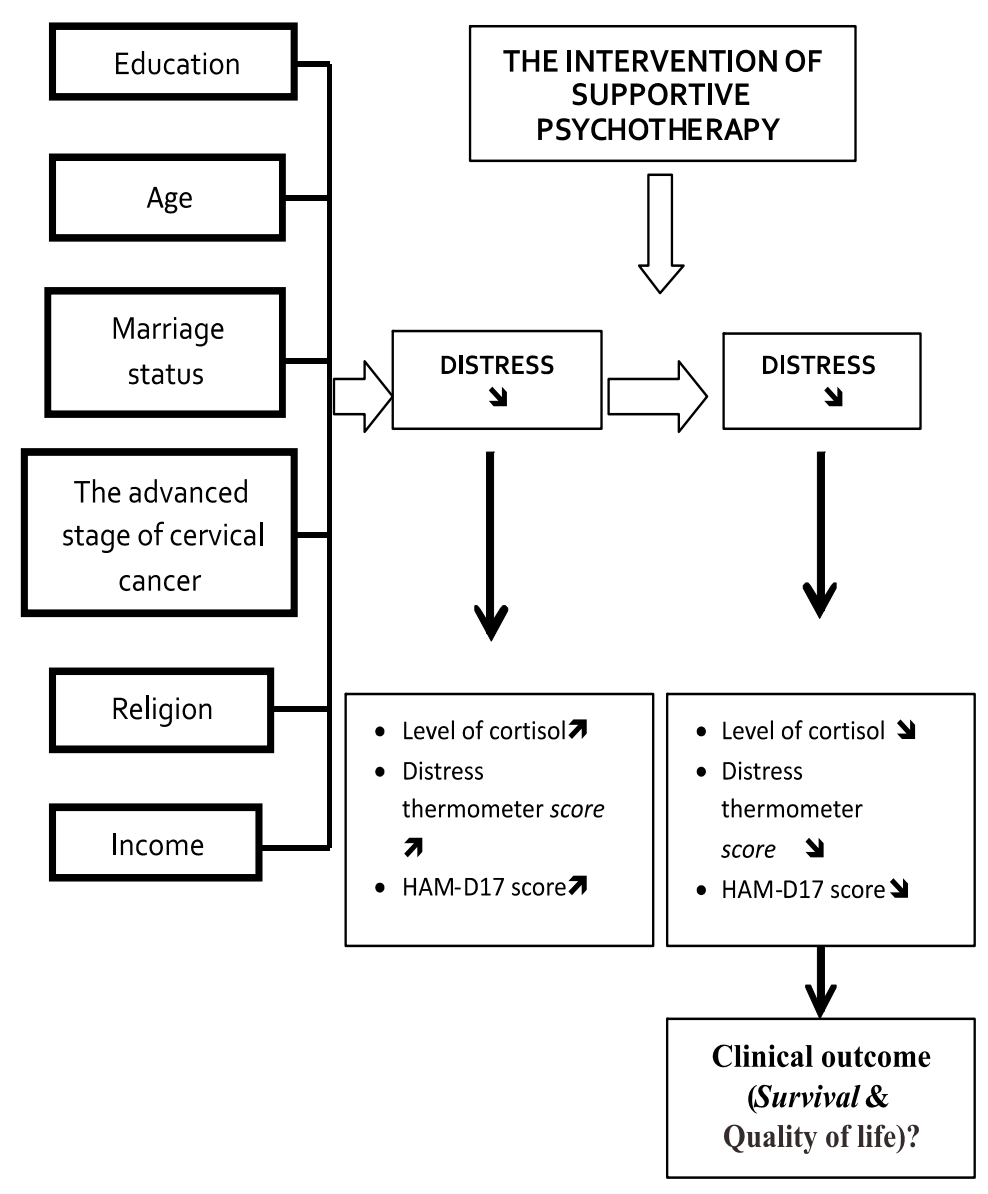




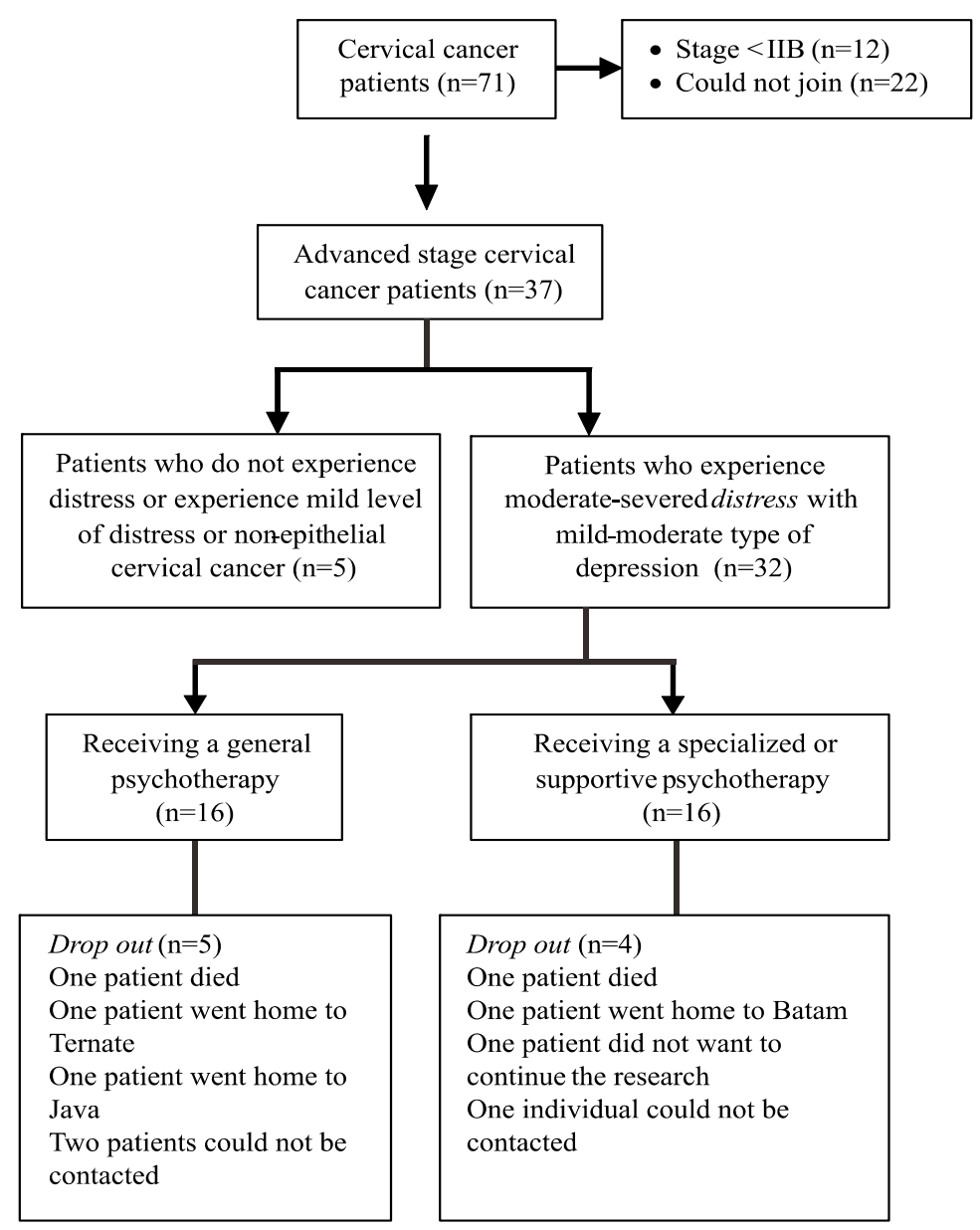

Distribution of cervical cancer patients based on stage of cervical cancer, as many as 9 (35\%) of people from the Group's treatment and $6(40.0 \%)$ those of the control group was at stadium II B. as much as one $(6.7 \%)$ people from the control group are at stage III A while on no treatment group $(0.0 \%)$. Then the respondents who are at stage III B in group treatment as 6 (37.5\%) of people and $8(53.3 \%)$ those of the control group. There is no respondent at stage IVA experiment and control group.

While respondents who are at stage IV B only 1 (6.3\%) people from the experiment group. Score the thermometer on the experiment group as well as score in the control group with the range of lowest value 5 and highest value 9, while the median value for distress thermometer was good in both groups. The value of $\mathrm{p}$ in the distribution stage of cancer, the distress thermometer score and HAM-D17 score entirely >0.05, means a control and experiment group are homogenous. Similarly, the value of $\mathrm{P}$ for the variable age, education, religion, ethnicity and employment in both research groups is $>0.05$, so it can be inferred that subject demographics research on experiment and control groups are homogeneous.

\section{Analysis of the Changes in Blood Cortisol Levels Before and After Supportive Psycho- therapy}

The lives of cancer cells are very supported by micro-environment around the cancerous tissue. Cancer and their micro environment able to produce interleukin pro-inflammation-6 (IL-6) cytokines. IL- 6 cytokines could trigger angiogenesis in cancer tissue micro environment, the growth and spreading of cancer cells. IL- 6 cytokines could facilitate the work of IL-1 (interleukin-1) and TNF- $\alpha$ (Tumor Necrotizing Factor- $\alpha$ ) in the hypothalamus then it can increase cortisol level in the blood. ${ }^{5}$

Chronic stress will disrupt along with the effect of increasing the final HPA T helper type 2 (Th2). Group T helper has special characteristics secreting cytokines lymphocytes and IFN- $\gamma \mathrm{T}$, which is already known as prototypes cytokines Th1 and IL-5 
as an indicator high polarized of Th2 cells, so it can be used to measure the level of each class $\mathrm{T}$ helper Immune Response. ${ }^{11} \mathrm{Th}-1$ is needed for an effective antitumor immunity and reportedly is also connected to increased the disease-free survival and overall survival. ${ }^{4,11}$

Then we conduct psychotherapy which aims to lower cortisol level. Prospective clinical trial research that evaluates the benefits of the therapy group supportive-expressive (SEGT/supportiveexpressive group therapy) on the survival of breast cancer patients who are already metastasize. Spiegel discovers the existence of benefits (positive effects) of psychotherapy in reducing growth/ progressiveness for breast cancer who do not have estrogen receptor, although there's no benefits on a group of patients that have estrogen receptors. ${ }^{7}$ Fawzy et al to evaluate both the initial and longterm effects of a group who get a structured intervention for six weeks which includes education about health, increased ability to resolve problems and distress management techniques. Maligna Melanoma patients among obtained a clear intervention benefits including reduced significant psychological distress and immunological changes when compared to the control group. At further control six years later of these patients, found an increase in the risk of recurrence and mortality occurred more in the control group than the group of patients with psychosocial interventions have been performed.

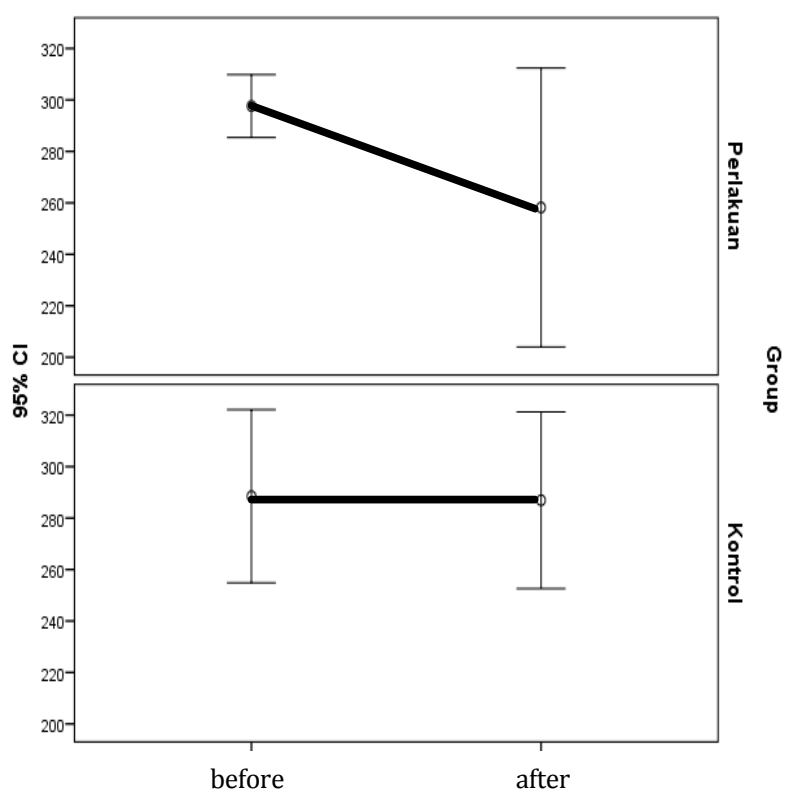

Figure 1. Blood Cortisol Level before and after Supportive Psychotherapy
From the results of cortisol in blood the whole subject of research, the median decrease in cortisol level obtained group treatment a lot more compared to the control group. There is blood cortisol level decrease in the treatment group of 39.43 whereas in the control group there was a decrease of 1.59 ( $\mathrm{p}=0.302)$. This shows the importance of supportive psychotherapy in order to lower blood level of cortisol.

The psychotherapy conducted in this study only as much as five times. Whereas in previous research, psychotherapy is done as much as 6-10 times and get the resulting improvement in the mood and the immune system of the patient. ${ }^{12}$ The least amount of meetings were given to patients due to the brevity of time research that resulted in a decrease in cortisol level in blood was not statistically significant. Another possible cause which made level of cortisol is not statistically significant was sampling time. The best time for taking samples of blood cortisol was in the afternoonevening cortisol level when the respondents returned to basic level of cortisol which only associated with the disease. ${ }^{4,5,11}$ Cortisol sampling performed when the respondents have arrived at RSCM after undergoing stressful conditions such as bogged down in a meaningful way to the Dr. Cipto Mangunkusumo Hospital.

\section{Analysis of Changes of the Distress Thermometer before and after Supportive Psychotherapy}

From the analysis results of thermometer score, obtained that the mean distress thermometer prior to psychotherapy in the treatment group was 6.12 (SB 1.67), whereas in control group was 6.44 (SB 1,32). After giving supportive psychotherapy, decreasing score happen in treatment group as average 3.4 and control group as 3.61 (p value > 0.492).

In addition to distress thermometer score, the study also unravels any problem encountered by respondents within the last week before measured the distress thermometer score. Researchers got the most problem complained that respondents from the control group were sad and painful feeling. While in the treatment group, the problems were obtained in the form of fear, anxiety, grief, worry, and pain. Almost all respondents revealed these problems diminished after got psychotherapy. 


\section{Analysis of the changes of HAM-D17 Score before and after Supportive Psychotherapy}

After the intervention of psychotherapy in the treatment group, HAM-D17 score is decreased with average score 7.53 (SB 3.34). Whereas in the control group also decreased with the average score 3.98 (SB 2.85). This difference is statistically and clinically significant, which means a decrease in the average HAM-D17 score between the treatment group and the control group has a value of $p$ $=0.003(\mathrm{p}<0.005)$. Based on the analysis results of summary according to distress level experienced by 32 respondents obtained 13 people from the control group experienced mild depression and three people suffered moderate depression. While in the treatment group, ten people suffered mild depression and six people experience moderate depression.

Table 1. HAM-D17 Score before and after Supportive Psychotherapy

\begin{tabular}{lccc}
\hline \hline \multirow{2}{*}{ HAM D17 } & \multicolumn{2}{c}{ Group } & p \\
\cline { 2 - 3 } & $\begin{array}{c}\text { Treatment } \\
(\mathrm{n}=16)\end{array}$ & $\begin{array}{c}\text { Control } \\
(\mathrm{n}=16)\end{array}$ & \\
\hline \multirow{2}{*}{ First } & 13.63 & 11.75 & 0 \\
& $(\mathrm{SB} 2.92)$ & $(\mathrm{SB} 2.72)$ & 0.070 \\
Second & $\begin{array}{c}6.10 \\
\text { (SB 2.60) }\end{array}$ & $\begin{array}{c}7.77 \\
(\mathrm{SB} 2.96)\end{array}$ & 0.100 \\
The Delta & -7.53 & -3.98 & \\
& $(\mathrm{SB} 3.34)$ & $(\mathrm{SB} 2.85)$ & 0.003 \\
\hline \hline
\end{tabular}

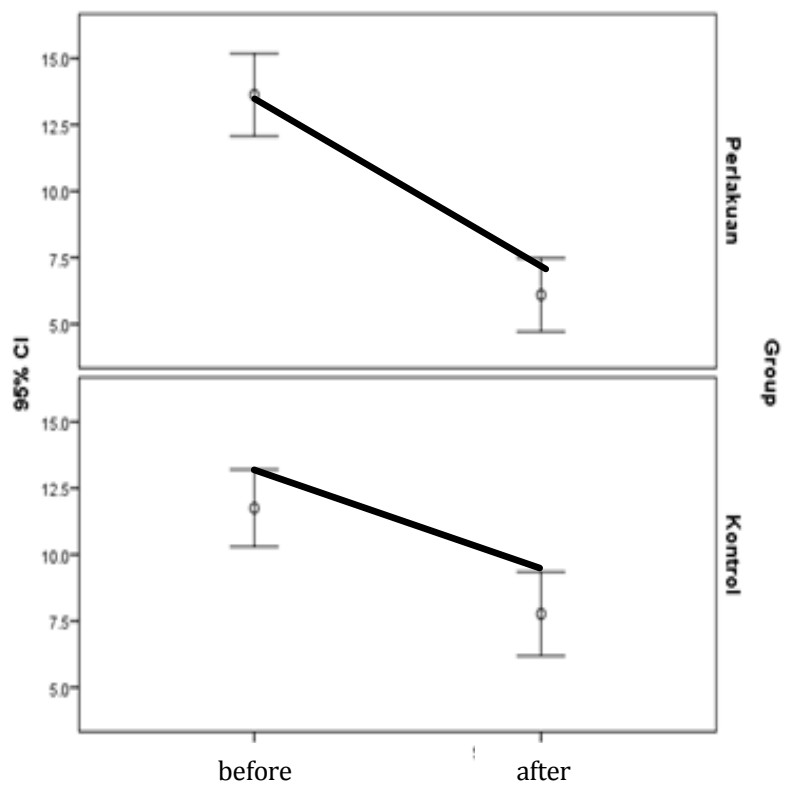

Figure 2. The Tendency of Decreasing Score HAM-D 17 before and after Supportive Psychotherapy
From the chart above, HAM-D17 score decreasing in treatment group seem steeper than in the control group and cortisol delta decreasing is statistically significant proven. This shows that supportive psychotherapy in advanced stage cervical cancer patients experienced mild and moderate depression disorders are very important. These results are in accordance with the results from various studies of supportive psychotherapy that psychotherapy is effective in lowering depression symptoms. As shown by the results of two metaanalyses done by Driessen et al. about the effectiveness of short-term psychodynamic psychotherapy. From 23 1,365 people, found a short-term dynamic psychotherapy more effective to decrease symptoms of depression. There was a lot of changes happened positively after therapy, and the results of the therapy remained until one year. When a comparison is done between techniques of psychotherapy and supportive expressive obtained there was no significant difference even though such therapy is given for three or 12 months. ${ }^{13}$

From research conducted by Cuijpers et al which compared 7 main types of psychosocial therapy for patients with mild to moderate depression that are cognitive behavioral therapy (CBT/Cognitive Behavioral Therapy), non supportive directive therapy, the activation behavior therapy, psychotherapy, dynamic problem solving therapy, interpersonal psychotherapy, and social skills training concluded that all of the psychosocial therapies have almost the same effectiveness, except interpersonal psychotherapy has slightly better effectiveness than the others while non supportive directive psychotherapy has a slightly lower effectiveness compared to others. ${ }^{13}$ Research by Goodwin et al about the effectiveness of expressive supportive psychotherapy in patients who have experienced metastatic breast cancer concluded psychotherapy resulted in the improvement of psychological symptoms, decrease in pain, change in the form of mood as well as changes in the perception of pain. ${ }^{11,14}$

From the results of research by Carlson et al., psychosocial therapies that are obtained in the form of Mindfulness Base Cancer Recovery and supportive group therapy - expressive given in breast cancer patients could improve the level of stress, social support, quality of life and diurnal cortisol profile. And from research by Nelson et al., psychosocial therapy such as Psychosocial Telephone Counseling (PTC) on the cervical cancer 
patients could significantly improve the quality of life and associated with the specific immune system changes mediated $\mathrm{T}$ helper cell group on cervical cancer patients. And finally, this condition resulted in improving and increasing life expectancy (survival rate). ${ }^{11,14}$

\section{Scoring System Using Multiple Variables to Predict Depression Levels}

Variables in the multivariate analysis at this stage are variable distress thermometer, cortisol, stage of cancer, marital status and parity. To find a point of intersection of these variables first performed bivariate analysis and continued to stage scoring.

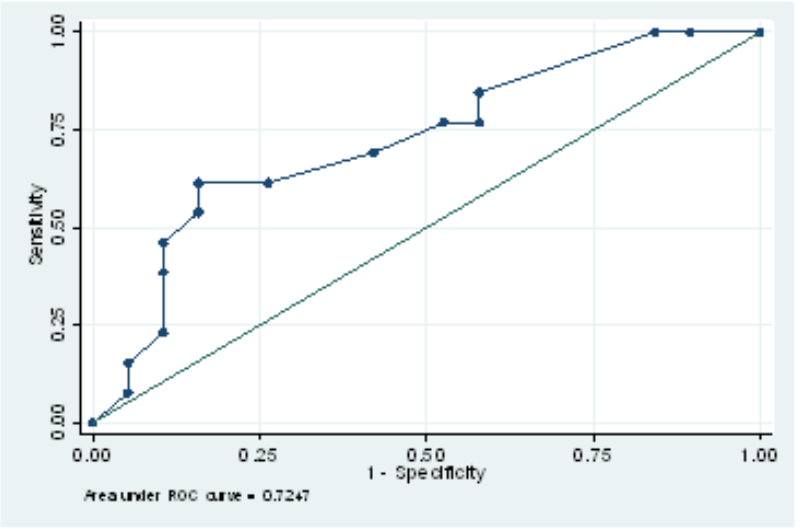

Figure 3. ROC of Variables in Predicting the Level of Depression

Table 2. The Final Model Results of Variable Predictor Scoring System for Depression

\begin{tabular}{|c|c|c|c|c|c|}
\hline Variables & Koef $(\beta)$ & SE & $\mathbf{p}$ & OR (IK 95\%) & Score \\
\hline Distress thermometer & 1.021 & 0.996 & 0.305 & $\begin{array}{c}2.776 \\
(0.394-19.568)\end{array}$ & 10 \\
\hline Cancer stage & 0.492 & 0.830 & 0.553 & $\begin{array}{c}1.636 \\
(0.322-8.318)\end{array}$ & 6 \\
\hline Cortisol & 1.309 & 0.873 & 0.134 & $\begin{array}{c}3.701 \\
(0.669-20.471)\end{array}$ & 15 \\
\hline Status of marriage & 0.612 & 0.906 & 0.499 & $\begin{array}{c}1.844 \\
(0.312-10.888)\end{array}$ & 7 \\
\hline Parity & 1.132 & 0.970 & 0.243 & $\begin{array}{c}3.103 \\
(0.464-20.769)\end{array}$ & 12 \\
\hline
\end{tabular}

Based on the table above, cut-off point curve, sensitivity, specificity and total score, the best cut point value for estimating the group of moderate depression in patients with epithelial cervical cancer is 32. Probability score of a patient experienced moderate depression can be seen in the table below.

Table 3. The Probability of a Predictor Score for Depression Level

\begin{tabular}{cccc}
\hline \hline Total score & Mild & Moderate & Probability \\
\hline$\geq 32$ & 2 & 6 & $75.0 \%$ \\
$<32$ & 17 & 7 & $29.2 \%$ \\
\hline \hline
\end{tabular}

From the analysis above could be inferred the ROC (Receiving Operating characteristic Curve) below. Determination of the final scoring model could predict the level of depression in epithelial cervical cancer patients as much as $72.47 \%$ with sensitivity $46.15 \%$ and specificity $89.47 \%$.

\section{CONCLUSION}

The prevalence of distress type depression in epithelial cervical cancer patients at RSCM as 45\%. Supportive psychotherapy in treating distress epithelial cervical cancer patients could lower cortisol level and the score of the distress thermometer. And the supportive psychotherapy had also proven lowering the score of HAM-D17 $(p=0.003)$. Supportive psychotherapy is very important in the treatment of cervical cancer patients who experienced distress type depression. Hopefully, the "team of Psycho-Oncology" or "Palliative care and pain management team" in RSCM would be formed so the cancer patients could be managed comprehensively.

\section{REFERENCES}

1. Holland JC, Alici Y. Management of Distress in Cancer Patients. J Supportive Oncol. 2010; 4-12. 
2. Holland JC, Jacobsen PB, Andersen B, et al. Distress Management. NCCN Clinical Practice Guidelines in Oncology, version 2. NCCN.org. 2014; 1-11.

3. Lederberg MS and Holland JC. Supportive Psychotherapy in Cancer Care: an Essential Ingredient of All Therapy. Handbook of Psychotherapy in Cancer Care, $1^{\text {st }}$ ed. 2011; 1: 3-13.

4. Limberaki E, Eleftheriou P, Gasparis G, et al. Cortisol level and serum antioxidant status following chemotherapy. Health. 2011; 3(8): 512-7.

5. Schrepf A, Clevenger L, Christensen D, et al. Cortisol and inflammatory processes in ovarian cancer patients following primary treatment: Relationships with depression, fatigue, and disability. Brain, Behavior Immun. 2013; 30: 12634.

6. Schrepf A, Thaker PH, Goodheart MJ, et al. Diurnal cortisol and survival in epithelial ovarian cancer. Psychoneuroendocrinol. 2015; 53: 256-67.

7. Volden PA and Conzen SD. The influence of glucocorticoid signaling on tumor progression. Brain, Behavior Immun. 2013; 30: 26-31.

8. Denaro N, Tomasello L, Russi EG. Cancer and stress: what's matter? From epidemiology: the psychologist and oncologist point of view. J Cancer Therapeutics Research. 2014;
3(6): 1-8.

9. Sannes TS, Jensen SE, Dodd SM, et al. Depressive symptoms and cortisol variability prior to surgery for suspected endometrial cancer. Psychoneuroendocrinol. 2013; 38: 241-9.

10. Raison CL and Miller AH. Depression in Cancer: New Developments Regarding Diagnosis and Treatment. Biol Psy. 2003; 54: 283-94.

11. Nelson EL, Wenzel LB, Osann K, et al. Stress, Immunity, and Cervical Cancer: Biobehavioral Outcomes of a Randomized Clinical Trial. Cancer Therapy: Clin. 2015; 2111-8.

12. Janice KK, McGuire L, Robles TF, Glaser R, et al. Psychoneuroimmunol: Psychological Influences on Immune Function and Health. J Consult Clin Psychol. 2002; 70(3): 537-47.

13. Jerachotechueantaveechai T, Charoenkwan K, Wongpakaran N. Prevalence and Predicting Factors for Anxiety in Thai Women with Abnormal Cervical Cytology Undergoing Colposcopy. Asian Pacific J Cancer Prev. 2015; 16: 1427-30.

14. Carlson LE, Doll R, Stephen J, et al. Randomized Controlled Trial of Mindfulness-Based Cancer Recovery Versus Supportive Expressive Group Therapy for Distressed Survivors of Breast Cancer (MINDSET). J Clin Oncol. 2013; 31: 1-9. 